\title{
Food Habits of Bryconaethiops boulengeri Pellegrin, 1900 (Characiformes: Alestidae) of Djiri River Tributary of the Right Bank of Congo River
}

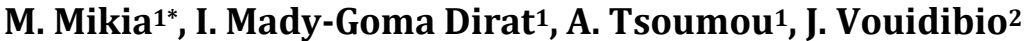 \\ ${ }^{1}$ Research Laboratory of Animal Biology and Ecology, ENS, University Marien Ngouabi, Brazzaville, Congo \\ ${ }^{2}$ Faculty of Sciences and Techniques, University Marien Ngouabi, Brazzaville, Congo \\ Email: *mmmikia@yahoo.fr
}

How to cite this paper: Mikia, M., Mady-Goma Dirat, I., Tsoumou, A. and Vouidibio, J. (2018) Food Habits of Bryconaethiops boulengeri Pellegrin, 1900 (Characiformes: Alestidae) of Djiri River Tributary of the Right Bank of Congo River. Open Journal of Ecology, 8, 510-521.

https://doi.org/10.4236/oje.2018.89031

Received: August 7, 2018

Accepted: September 22, 2018

Published: September 25, 2018

Copyright $\odot 2018$ by authors and Scientific Research Publishing Inc. This work is licensed under the Creative Commons Attribution International License (CC BY 4.0).

http://creativecommons.org/licenses/by/4.0/

\begin{abstract}
Diet of 300 specimens of Bryconaethiops boulengeri from Djiri River (Congo Brazzaville) caught with cash nets was studied according to the size of fish, sampling stations and hydrological season. Sampling focused on twelve annual withdrawals made during three years. The relative importance index combining numerical and weight percentages of occurrence was calculated and also the sex ratio was evaluated. Bryconaethiops boulengeri consumes terrestrial and aquatic insects and everything that falls into the water (birds feathers, plant debris, fruits, etc.). The percentage of emptiness is $9.66 \%$ of the three sampling stations selected; no significant difference in diet was observed whatever the season.
\end{abstract}

\section{Keywords}

Djiri River, Bryconaethiops boulengeri, Food Habits, Occurrence, Eclectic Insectivore

\section{Introduction}

Bryconaethiops boulengeri is an Alestidae widespread throughout the Congo Basin [1], mostly found in Alima River [2] and in Léfini River [3]. Moreover, Bryconaethiops boulengeri, Bryconaethiops microstoma, Micralestes stormsi and Synodontis nigriventris are the most abundant species found in the Djiri River [4]. However, very little information is available on the biology, ecology, mainly their food habits. It should be noted that a major study of fishes ecology 
and ethology conducted in Lake Tumba and Ikela region provided qualitative data on food habits of $B$. boulengeri [5]. This present study gives information on nutrition, diet change according to the environment, season and the size of $B r y$ conaethiops boulengeri.

\section{Materials and Methods}

\subsection{Study Area}

Djiri River is located in the $9^{\text {th }}$ district of Brazzaville rises in the southern hiller Mbé and the high hills that extend to the Batékés plates. Length is about $50 \mathrm{~km}$ covering an area of $853 \mathrm{~km}^{2}$, of $850 \mathrm{~mm}$ flow by year, the deficit flow is $960 \mathrm{~mm}$, a flow rate of $27 \mathrm{l} / \mathrm{s} / \mathrm{km}^{2}$ and a flow coefficient of $47 \%$. Djiri River flowing in the direction NW-SE main tributaries Kouala-Kouala, Bamba and Souo on its left bank and Bilolo and Bitatolo on its right bank [6]. The sampling area is located between 04.18117 to 04.13095 South latitude 15.31177 to 015.32192 east longitude (Figure 1).

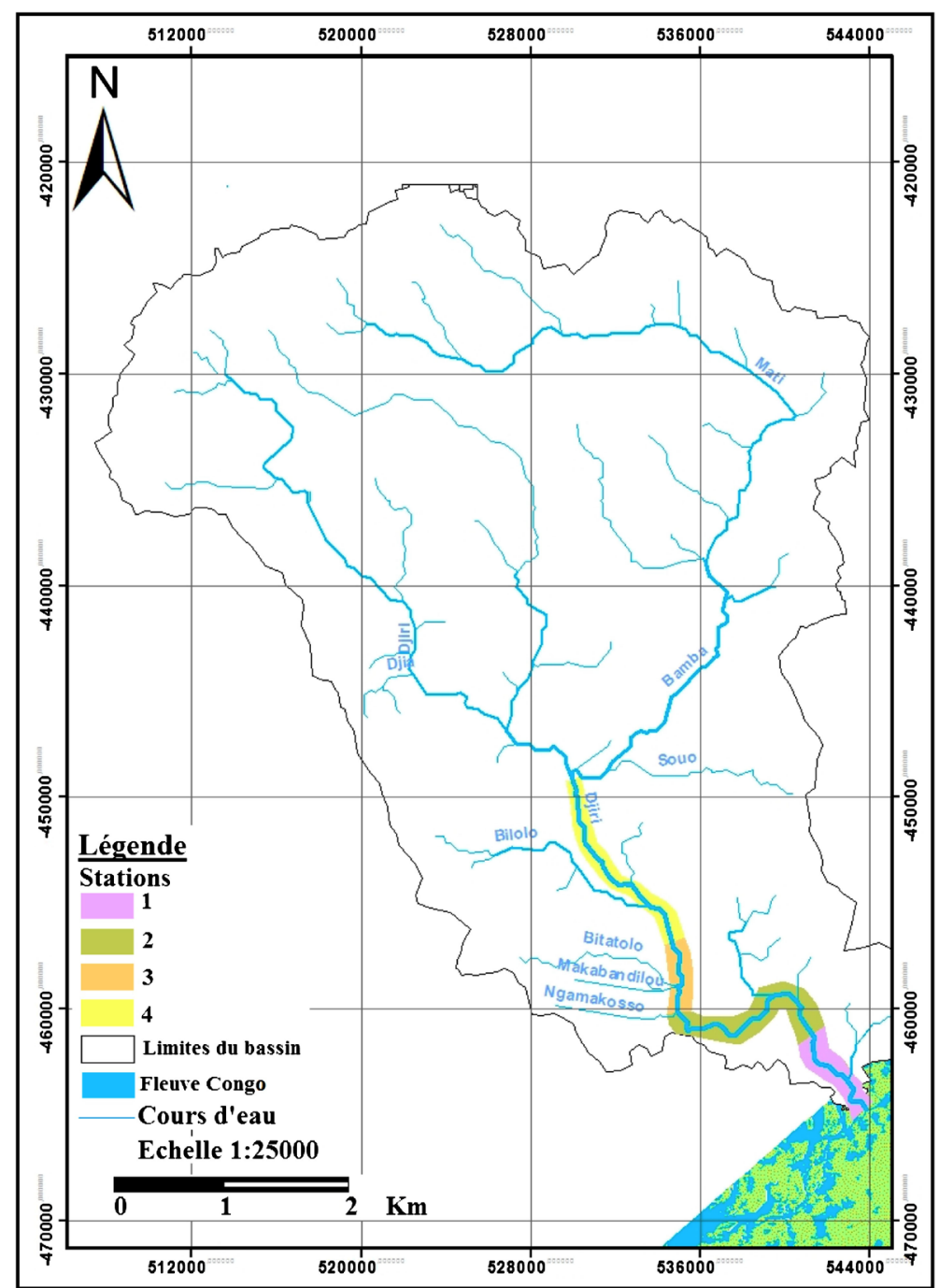

Figure 1. Study area (SRTM picture "Shut Radar Mission 2000”). 


\subsection{Sampling and Analyzes}

Fishes were caught in the lower reach of Djiri River during monthly fishing trips from February 2008 to January 2011. They were immediately fixed in formalin $10 \%$ and then transferred the next day in 5\% formalin for preservation. Each specimen was weighted to the nearest milligram and measured (standard length). The stomach contents were then diluted in water and examined under a binocular microscope. Different food taxa were sorted and identified, when their state of degradation permitted, according to Lausanne protocol [7].

\subsection{Percentage of Emptiness}

The percentage of emptiness was estimated as the following formula.

$$
V=\frac{N_{v}}{N_{t}} \times 100
$$

$N_{\dot{r}}$ number of empty stomachs.

$N_{i}$ total number stomachs examined.

\subsection{Intestinal Coefficient}

The digestive tract has been described from 300 individuals whose are between. Intestinal coefficient $(C)$ is calculated following the formula [8].

$$
C l=\frac{L i}{L s}
$$

Li: intestinal length.

Ls. standard length.

\subsection{Percentage of Occurrence}

The percentage of occurrence was calculated according to the following formula [9].

$$
\% O c=\frac{n_{i}}{N_{T}} \times 100
$$

$n_{i}=$ number of stomachs containing a category of preys.

$N_{T}=$ total number of full stomachs examined.

\subsection{Preponderance Index}

To quantify the relative importance of prey, the following indices were calculated: percentage of occurrence and weight percentage [10]. To avoid biases related to the use of these indices, the preponderance index [11] that incorporates these two indices was estimated with the following formula.

$$
I p=\frac{\% O c \times \% P}{\sum(\% O c \times \% P)} \times 100
$$

$I p$ : preponderance index.

$\% P$. weight percentage. 
Different preys categories are classified According to the values of preponderance index.

$-I p<10$ : accessory prey.

$-10<I p<25$ : secondary prey.

$-25<I p<50$ : important prey.

- Ip > 50: main prey.

A hierarchical cluster analysis (single linkage cluster analysis) was used to highlight the similarities between trophic stations and classes size. Classes size were determined according to the rule of Sturge [12].

$$
\begin{aligned}
& N C=1+\frac{10 \log _{10} N}{3} \\
& I=\frac{L S \max -L S \min }{N C}
\end{aligned}
$$

$N C$ : Number of classes size.

I: interval of classes.

$N$ : total number of classes.

$L S$ max: maximum length standard.

$L S$ min: minimum length standard.

The index of Schoener was used to assess the degree of similarity between the different seasons, stations and classes size [13].

$$
\alpha=1-0.5\left(\sum_{i=1}^{n}|P x i-P y i|\right)
$$

$P_{x i}$ : proportion of prey $i$ consumed by a mature stage (individuals in a season).

Pyi: proportion of prey $i$ consumed by a mature stage (individuals of the season).

The diets are considered substantially similar if the Schoener index $\alpha$ is greater than or equal to 0.6 [13].

\section{Results}

The digestive tract is formed of a thick-walled esophagus, followed by a $U$ shaped stomach surrounded by pyloric caeca. There are an average of 8 pyloric caeca and intestine is curled (Figure 2).

There was a significant linear relationship between the length of the intestine and the standard length of the fish $(\mathrm{r}=0.84, \mathrm{p}<0.05)$. Intestinal coefficient of 300 individuals analyzed varies between 0.71 and 1.29 with an average of $0.95 \pm$ 0.48 (Figure 3). The intestine of Bryconaethiops boulengeri is so short.

\subsection{General Profile of the Diet}

Of the three hundred Bryconaethiops boulengeri stomachs examined, 29 were empty, a percentage of $9.66 \%$ of emptiness. Seventeen categories of food divided into five groups were identified (Table 1): insects, arachnids, crustaceans, nemathelminths, macrophytes and others (fish scales, birds feathers, plastic bags). The weight index shows that preferential foods B. boulengeri are coleoptera (32.7\%) 


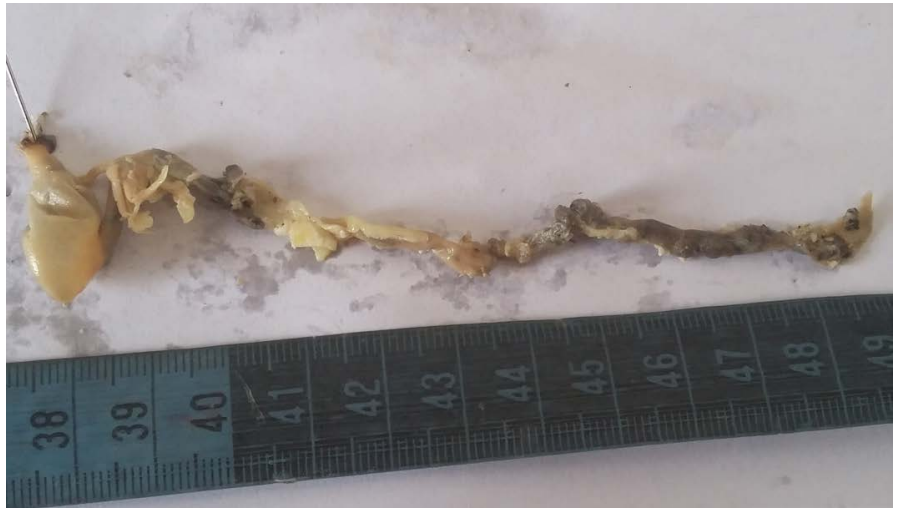

Figure 2. Digestive tube of Bryconaethiops boulengeri.

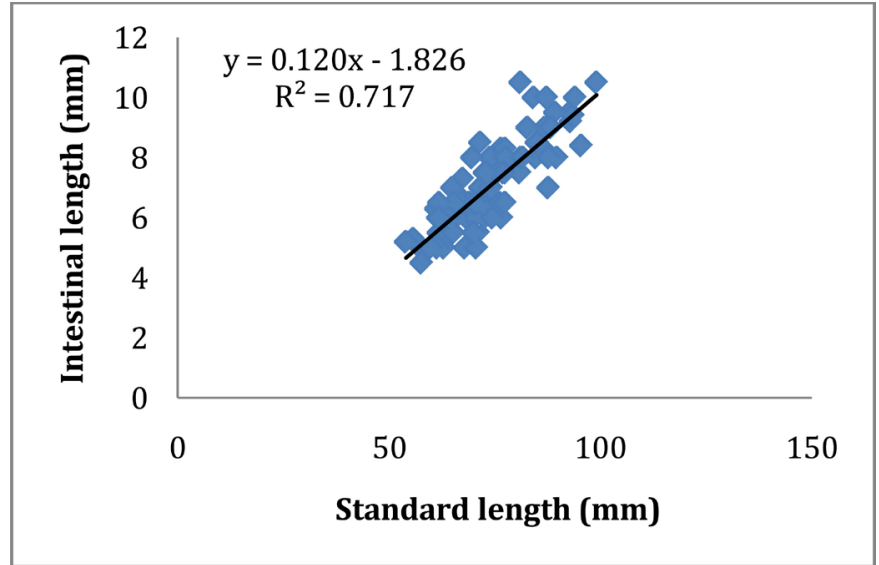

Figure 3. Relationship between intestinal length and standard length of $B$. boulengeri.

followed by odonata larvae (26.97\%) and ephemeroptera (25.9\%). The analysis of stomach contents showed that Bryconaethiops boulengeri consumes mainly insects (coleoptera, ephemeroptera and odonata larvae) with a preponderance index of 90.19 followed by macrophytes (dicot leaves and plant debris) with a preponderance index of 8.17 .

\subsection{Qualitative and Quantitative Aspects of Diet}

Food items found in the stomachs of fish one spread over animal and plant fractions (Table 1). Animal fraction contains 17 items divided into six classes: insects, arachnids, shellfish, nematodes, fish, birds feathers. The fraction consists in plant leaf, fruit and stems of dicotyledonous. The classification of preys by calculating the preponderance index (Ip) has classified insects $(90.19 \%)$ in the category of main prey and macrophytes $(8.17 \%)$ as accidental prey.

\subsection{Study of the Diet According to Season}

Insects are the main preys eaten by Bryconaethiops boulengeri whatever the season, with a preponderance index $83.60 \%$ in the rainy season against $86.61 \%$ in the dry season. Macrophytes are secondary preys during two seasons with a preponderance index of $10.80 \%$ in the rainy season and $12.70 \%$ in the dry sea- 
son. Beetles are important preys in the rainy season followed by Ephemeroptera and Odonata larvaes that are secondary preys (Table 2). In the dry season, Ephemeroptera and Odonata larvae are important preys followed by beetles that are secondary preys. Schoener index between the two seasons is 0.89 . The study of diet depending on the hydrological season shows no significant difference between the dry season and the rainy season (Schoener index $=0.89$ ). This diet

Table 1. Composition of diet Bryconaethiops boulengeri in Djiri River Oc $=\%$ occurrence; $\% \mathrm{P}$ = weight percentage; $\mathrm{Ip}=$ preponderance index.

\begin{tabular}{|c|c|c|c|c|}
\hline \multicolumn{2}{|r|}{ Preys } & \multirow{2}{*}{$\begin{array}{l}\% \text { Oc } \\
22.33\end{array}$} & \multirow{2}{*}{$\begin{array}{c}\text { \%P } \\
22.32\end{array}$} & \multirow{2}{*}{$\begin{array}{c}\text { Ip } \\
32.704\end{array}$} \\
\hline & Coleoptera & & & \\
\hline & Odonata larvae & 20.67 & 19.89 & 26.977 \\
\hline & Ephemeroptera & 22.33 & 17.68 & 25.905 \\
\hline & Hymenoptera & 8.33 & 5.19 & 2.837 \\
\hline & Plecoptera & 5 & 3.21 & 1.053 \\
\hline \multirow[t]{6}{*}{ Insects } & Lepidoptera & 4 & 1.97 & 0.517 \\
\hline & Diptera & 2 & 1.25 & 0.164 \\
\hline & Orthoptera & 0,67 & 0.29 & 0.013 \\
\hline & Trichoptera & 0.67 & 0.2 & 0.009 \\
\hline & Hemiptera & 0,33 & 0,43 & 0.009 \\
\hline & Total & 86.33 & 72.43 & 90.19 \\
\hline Arachnids & Spiders & 0.33 & 0.1 & 0.002 \\
\hline Crustaceans & Shrimps & 2.67 & 6.08 & 1.065 \\
\hline \multirow[t]{2}{*}{ Nematodes } & $\mathrm{Ni}$ & 0.67 & 0.75 & 0.033 \\
\hline & Fruits & 3.67 & 2.08 & 0.501 \\
\hline \multirow{5}{*}{ Macrophytes } & Sheet Dicotes & 7.67 & 8.94 & 4.499 \\
\hline & Plant debris & 9.33 & 5.18 & 3.171 \\
\hline & Total & 20.67 & 16.2 & 8.171 \\
\hline & Scales & 2.67 & 0.89 & 0.468 \\
\hline & meat and fish bones & 1 & 1.29 & 0.085 \\
\hline \multirow[t]{3}{*}{ Other foods } & Birds feathers & 1 & 0.34 & 0.022 \\
\hline & Grease & 2.67 & 1.64 & 0.287 \\
\hline & Bag & 0.67 & 0.31 & 0.014 \\
\hline
\end{tabular}

Table 2. Composition of the dominant items in the diet of B. boulengeri in Djiri River according to season (Ip).

\begin{tabular}{ccc}
\hline Preys & Saison de Pluies $(\mathrm{n}=135)$ & Saison Sèche $(\mathrm{n}=136)$ \\
\hline Coleoptera & 40.70 & 24.44 \\
Odonata & 21.30 & 28.54 \\
Ephemeroptera & 19.20 & 28.66 \\
\hline
\end{tabular}


similarity between the two seasons could be related to the fact that Djiri River did not have a strong period of floods and low flows.

The affinity of prey consumed between the two seasons dendrogram shows no discrimination regime between the two seasons (Figure 4). Two groups of preys are discriminated, prey to high consumption (Coleoptera, Odonata larvae and that of Ephemeroptera) forming group 1 and those of low consumption (dicot leaves, plant debris and other Hymenoptera).

\subsection{Study Diet According to Stations}

Insects are the main prey of Bryconaethiops boulengeri, whatever the station with a preponderance index of $84.44 \%$ at station $1,94.34 \%$ to $83.35 \%$ and station 2 to station 3. Macrophytes are secondary prey in station 3 with $16.6 \%$ of weight and accessory prey at station 1 and 2 respectively with a preponderance index of $9.03 \%$ and $2.58 \%$ (Table 3 ).

Among insects, Coleoptera, the Ephemeroptera and Odonata larvae are most consumed in the three stations (Table 4).

An isolated sequence provided by the station 1, it has relatively low affinities of diet with the stations 2 and 3. The hierarchical cluster analysis performed on the basis of index calculated in each different station isolates the feed station 1 to the other two stations (Figure 5).

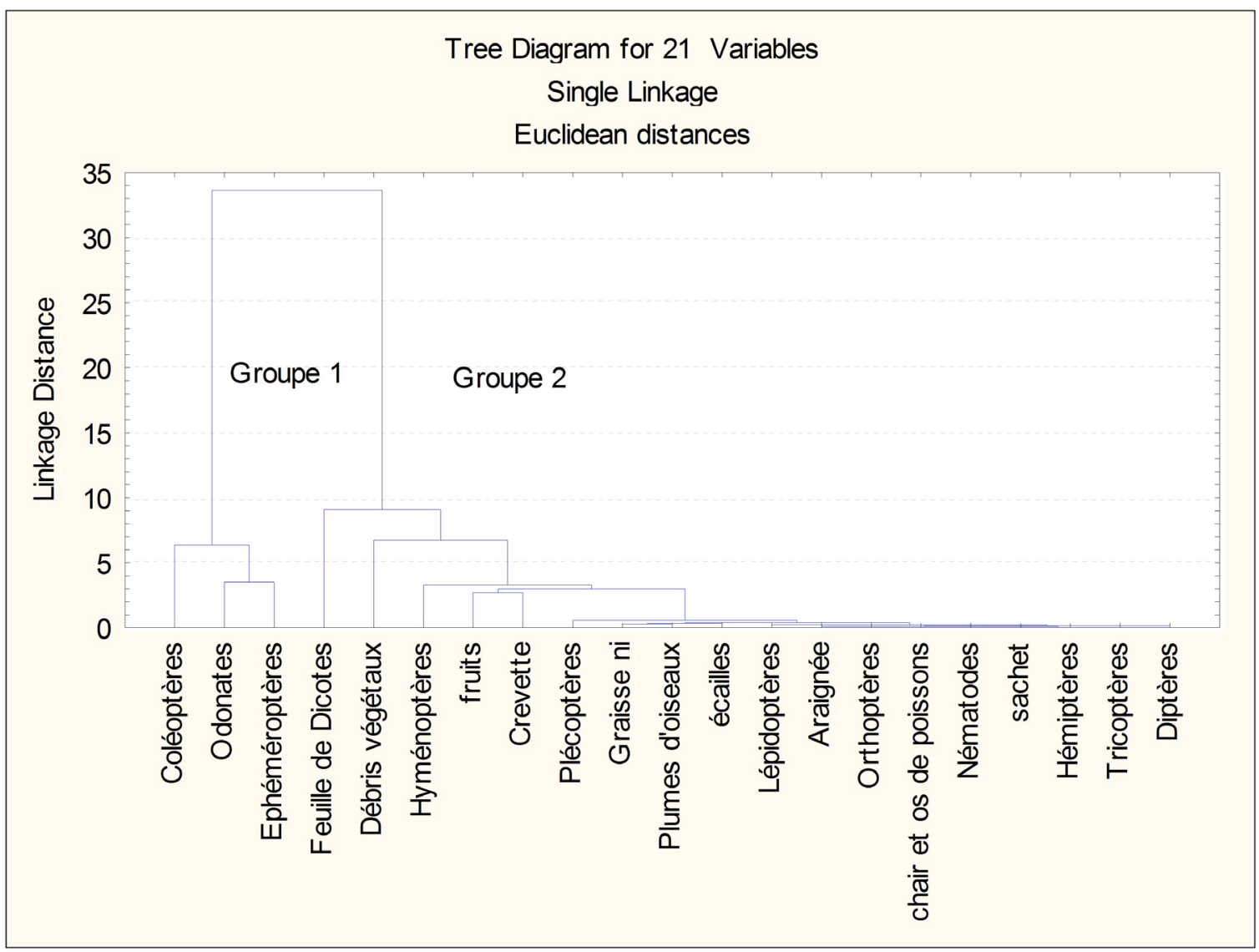

Figure 4. Affinity dendrogram of different food items according to season. 
Table 3. Composition of food items B. boulengeri in Djiri River according to station (Ip).

\begin{tabular}{cccc}
\hline Preys & Station $\mathbf{1}(\mathbf{n}=\mathbf{9 1})$ & Station $\mathbf{2}(\mathbf{n}=\mathbf{9 1})$ & Station 3 $(\mathbf{n}=\mathbf{9 0})$ \\
\hline Insects & 84.44 & 94.34 & 83.35 \\
Macrophytes & 9.03 & 2.58 & 16.6 \\
Crustaceans & 2.62 & 2.45 & 0.01 \\
Fish scales & 1.15 & 0 & 0 \\
Nematodes & 0.01 & 0.15 & 0 \\
Bird's feathers & 0.01 & 0.05 & 0.01 \\
Arachnids & 0 & 0 & 0.01 \\
\hline
\end{tabular}

Table 4. Composition of the dominant food items B. boulengeri in Djiri River according to station (Ip).

\begin{tabular}{cccc}
\hline Preys & Station $\mathbf{1}(\mathbf{n}=\mathbf{9 1})$ & Station $\mathbf{2}(\mathbf{n}=\mathbf{9 1})$ & Station $\mathbf{3}(\mathbf{n}=\mathbf{9 0})$ \\
\hline Ephemeroptera & 24.21 & 29.87 & 20.61 \\
Coleoptera & 14.73 & 36.22 & 39 \\
Odonata & 37.13 & 26.22 & 18.8 \\
\hline
\end{tabular}

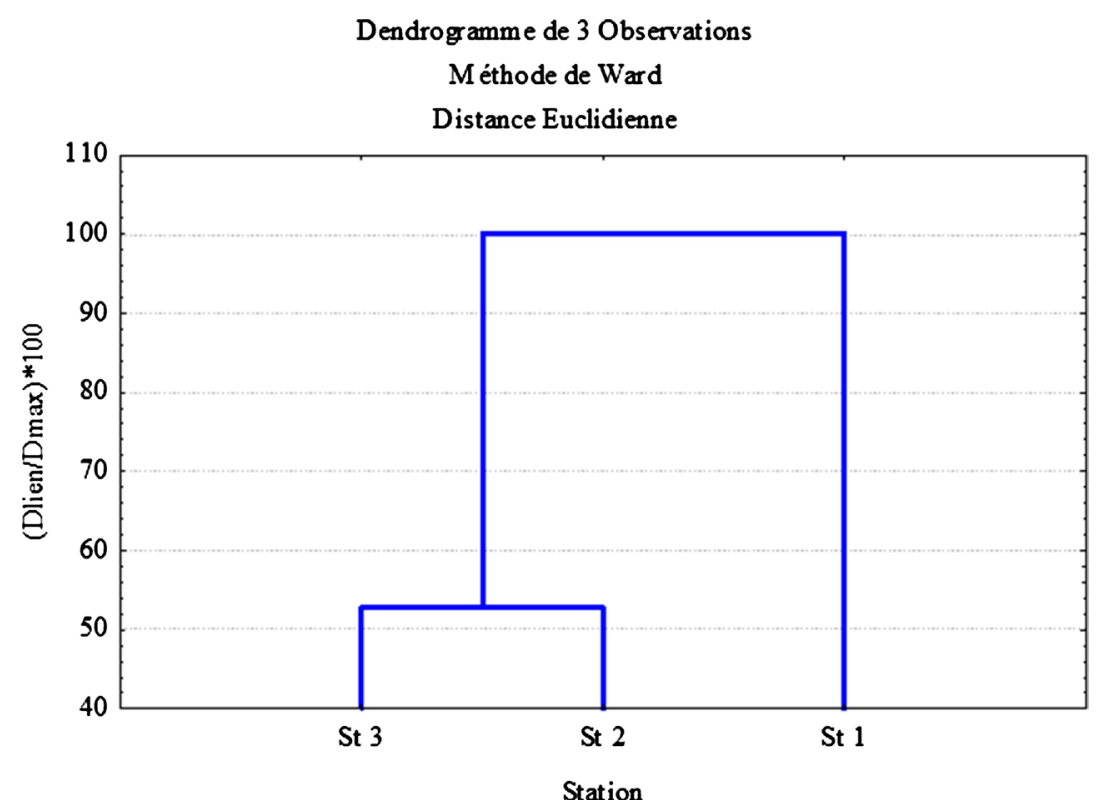

Figure 5. Affinity dendrogram of different food items according to station.

There is no significant variation in diet among the three sampling stations. Schoener index is equal to 0.87 between the first and second biotope of 0.88 between second and third biotope and 0.86 between the first and third biotope. This observation confirms that the diet of a species is substantially the same throughout its range [10].

\subsection{Study of the Diet According to Size}

Specimens examined were between 39.6 and $114.6 \mathrm{~mm}$ standard length. Nine 
classes size were determined according to the Sturge rule (Table 5). Due to the very low numbers, class 1 was fused to Class 2 and Class 9 is fused to Class 8 .

Class $1(\mathrm{n}=1): 39 \leq \mathrm{LS}<47.5 \mathrm{~mm}$; Class $2(\mathrm{n}=13): 47.5 \leq \mathrm{LS}<56 \mathrm{~mm}$; Class 3 ( $\mathrm{n}=49): 56 \leq \mathrm{LS}<64.5 \mathrm{~mm}$; Class $4(\mathrm{n}=69): 64.5 \leq \mathrm{LS}<73 \mathrm{~mm}$; Class $5(\mathrm{n}=$ 62): $73 \leq$ LS < $81.5 \mathrm{~mm}$; Class $6(\mathrm{n}=46): 81.5 \leq \mathrm{LS}<90 \mathrm{~mm}$; Class $7(\mathrm{n}=24): 90$ $\leq \mathrm{LS}<98.5 \mathrm{~mm}$; Class 8 ( $\mathrm{n}=5): 98.5 \leq \mathrm{LS}<107 \mathrm{~mm}$; Class $9(\mathrm{n}=1): 107 \leq \mathrm{LS}<$ $1155 \mathrm{~mm}$.

The hierarchical cluster analysis performed on the basis of different weight calculated in each class size food index, allows us to consider four groups of classes size (Figure 6). Group 1 consists of specimens of the $7^{\text {th }}$ class; group 2 consists of specimens of the sixth class, group 3 specimens consisting of the $4^{\text {th }}$, $5^{\text {th }}$ and $8^{\text {th }}$ classes, and finally the group consisting of 4 specimens of the second and third classes.

Table 5. Composition of food items B. boulengeri in Djiri River according to size (Ip).

\begin{tabular}{cccccccc}
\hline & $\begin{array}{c}\text { Class 2 } \\
(\mathrm{n}=14)\end{array}$ & $\begin{array}{c}\text { Class 3 } \\
(\mathrm{n}=49)\end{array}$ & $\begin{array}{c}\text { Class 4 } \\
(\mathrm{n}=69)\end{array}$ & $\begin{array}{c}\text { Class 5 } \\
(\mathrm{n}=62)\end{array}$ & $\begin{array}{c}\text { Class 6 } \\
(\mathrm{n}=46)\end{array}$ & $\begin{array}{c}\text { Class 7 } \\
(\mathrm{n}=24)\end{array}$ & $\begin{array}{c}\text { Class 8 } \\
(\mathrm{n}=6)\end{array}$ \\
\hline Insects & 99.40 & 98.08 & 85.08 & 87.68 & 92.55 & 88.1 & 87.4 \\
Arachnids & 0.00 & 0 & 0 & 0 & 0.04 & 0 & 0 \\
Crustaceans & 0.00 & 0 & 0.04 & 0.25 & 1.19 & 5.4 & 2.52 \\
Nematodes & 0.00 & 0 & 0.08 & 0 & 0 & 0 & 0 \\
Macrophytes & 0 & 1.93 & 14.55 & 10.74 & 5.6 & 3.7 & 9.7 \\
Fish scales & 2.3 & 0 & 0.21 & 0.58 & 0.25 & 1.8 & 0 \\
Birds feathers & 0 & 0 & 0.01 & 0 & 0.18 & 0.8 & 0 \\
\hline
\end{tabular}

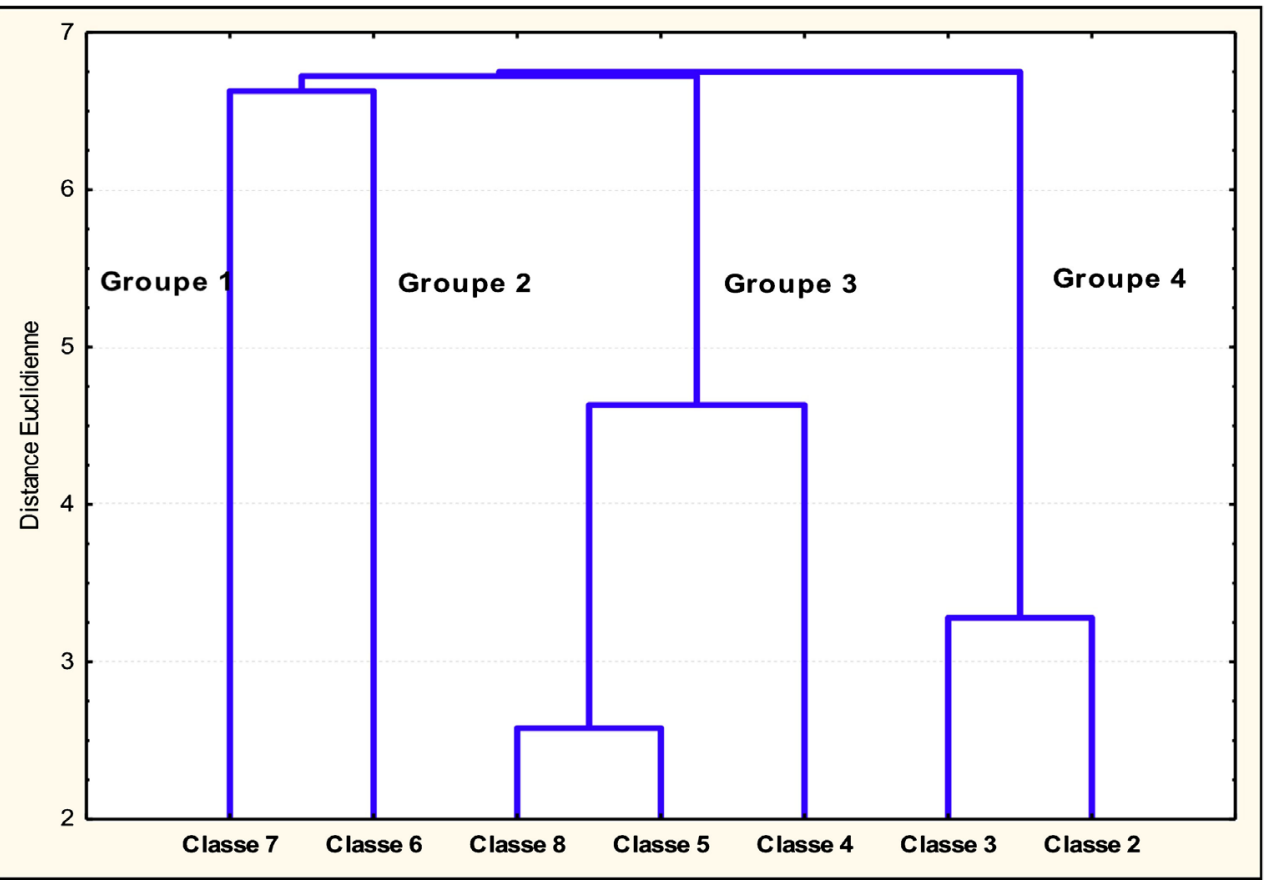

Figure 6. Dendrogram affinity of various food items according to classes size. 
Insects are the main prey of Bryconaethiops boulengeri in all groups of classes size. The Macrophytes are secondary preys in class 4 and class 5 . All other items are the some accessories preys either group. Furthermore, no significant difference was observed between individuals of different size, the Schoener index is greater than 0.60 between the four groups. However, the similarity dendrogram regime reveals that individuals in the group 3 (class 4 , class 5 and class 8 ) consume more macrophytes than other groups, this result shows that the young fishes of group 4 (class 2 and class 3 ) feed almost exclusively insects and they incorporate other foods into their diet with age (size superior to $64.5 \mathrm{~mm}$ ).

\section{Discussion}

The intestinal coefficient of the 300 individuals of Bryconaethiops boulengeri varies between 0.71 and 1.29, with an average of $0.95 \pm 0.01$.The intestine is usually short in carnivores, less than two standard and long length herbivores two to eight times the standard length [14] [15]. From a qualitative point of view, the stomach contents analyse are consistent with those of Lac Tumba and Ikela region [5], who reports that Bryconaethiops boulengeri is polyphagous. Stomach contents include plant debris, sometimes some sand, and insect debris (nymphs of Ephemeroptera and odonates), ants, small Hymenoptera and Coleoptera. Quantitative analysis of the stomach contents of Bryconaethiops boulengeri shows that it consumes mainly insects (Coleoptera, Ephemeroptera and odonate larvae) with a preponderance index of 90,188 followed by macrophytes (dicotyledonous leaves and plant debris) with a preponderance index of 8.17. However, considering the two aspects of the diet (the qualitative and quantitative contributions), it seems clear that this fish is entomophagous. The study of the diet according to the hydrological season shows no significant difference between the dry season and the rainy season (Schoener index is 0.89). This similarity could be linked to the fact that the Djiri River does not experience a strong period of floods and low flows. These results are consistent with the authors who report that the diet of fish in rivers that do not overflow does not change significantly. There is no significant variation in diet between the three sampling stations [7] [16]. The Schoener index is 0.87 between the first and second biotopes, 0.88 between the second and third biotope, and 0.86 between the first and third biotope. This observation confirms that the diet of a species is substantially the same throughout its range [7]. There is not significant change in the diet of Bryconaethiops boulengeri as a function of height, the Schoener index being greater than 0.6. From this study, only one trophic guild is identified according to size, season or station at Bryconaethiops boulengeri, the nature of the prey items consumed by the young remains strictly identical to those ingested by adults. Intraspecific competition would be great because it offers a reduced exploitable food spectrum by individuals of the same species. In this species, the exploitation of the same food resource would lead to an intraspecific competition for the exploited common resource [8] [17]. However, this kind of competition can be 
avoided because if the diet remains insectivorous, three main biological groups (Coleoptera, Odonata larvae, Hymenoptera) considered as prey organisms constitute the preponderant food of Bryconaethiops boulengeri at all sizes, at all levels in all seasons and in all stations.

\section{Conclusion}

The analysis of 271 digestive tubes of Bryconaethiops boulengeri of Djiri River allows us to conclude that this species is insectivorous, it operates relatively well available food resources (because the coefficient of emptiness is low), it means that, the sustainability of resource, could explain the subjugation of this species in streams tributary of the Congo River. The food always available limits the width of the trophic recess. The speed variation depending on season, size class or station is not significant. It is desirable to extend this study to the reproduction in order to complete data on the bioecology of this species.

\section{Acknowledgements}

We thank Professor H. Banga Mboko, National High School of Agronomy and Forestery, Marien Ngouabi University, Brazzaville, Congo, for his comments and suggestions.

\section{Conflicts of Interest}

The authors declare no conflicts of interest regarding the publication of this paper.

\section{References}

[1] Paugy, D. (1986) Révision systématique des Alestes et Brycinus africains (pieces Characidae). Collection Etudes et Thèses, ORSTOM, Paris, 295 p.

[2] Mady-Goma Dirat, I., Tsoumou, A. and Vouidibio, J. (2006) Données préliminaires sur l'ichtyofaune de la basse Alima (bassin du Congo). In: Mbongui, revue pluridisciplinaire de recherche université Marien Ngouabi, 39-52.

[3] Ibala Zamba, A. (2010) Faune des poissons des rivières Luki et Lefini (Bassin du Congo): Diversité et Ecologie. Thèse de doctorat $(\mathrm{PhD})$ en Sciences, Université de Leuven, Leuven, $452 \mathrm{p}$.

[4] Mikia, M., Mady-Goma Dirat, I., Tsoumou, A., Mabanza J. and Diatewa, M. (2013) Preliminary Data on the Ichtyofauna of Djiri River (Affluent of Right Bank of Congo River). International Research Journal of Environment Sciences, 2, 1-5.

[5] Matthes, H. (1964) Les poissons du lac Tumba et de la région d'Ikela, Etude Systématique et Ecologique. Musée Royal de l'Afrique Centrale, Tervuren, 126, 45-50.

[6] Moukolo, N. (1984) Ressources en eau souterraine et approvisionnement. Essai d'analyse socio-économique en région équatoriale humide (Régions de Brazzaville et de Pointe-Noire, Congo). Thèse de 3e cycle de l'Académie de Montpellier, 5-50.

[7] Lauzanne, L. (1988) Les habitudes alimentaires des poissons d'eau douce africains. In: Lévêque, C., Bruton, M.N. and Ssentongo, G.W., Eds., Biologie et écologie des poissons d'eau douce africains, ORSTOM, Paris, France, 221-242. 
[8] Kouamelan, E.P., Teugels, G.G., Gourene, G., Thys Van Den Audenaerde, D.F.E. and Ollevier, F. (2000) Habitudes alimentaires de Mormyrops anguillö̈des (Mormyridae) en milieux lacustre et fluvial d'un bassin ouest africain. Cybium, 24, 67-79.

[9] Rosecchi, E. and Nouaze, Y. (1987) Comparaison de cinq indices utilisés dans l'analyse des contenus stomacaux. Revue des Travaux de l'Institut des Pêches Maritimes, 49, 111-123.

[10] Hynes, H.B.N. (1950) The Food of Fresh Water Sticklebacks (Gasterosteus aculeatus and Pygosteus pungitius) with a Review of Methods Used in Studies of the Food of Fishes. Journal of Animal Ecology, 19, 36-58. https://doi.org/10.2307/1570

[11] Natarajan, A.V. and Jhingran, A.G. (1961) Index of Preponderance-A Method of Grading the Food Elements in the Stomach Analysis of Fishes. Indian Journal of Fisheries, 8, 54-59.

[12] Schereck, C.B. and Moyle, P.B. (1990) Methods for Fish Biology. American Fisheries Society Bethesda, Maryland, USA, $684 \mathrm{p}$.

[13] Schoener, T.W. (1970) Non-Synchronous Spatial Overlap of Lizards in Patchy Habitats. Ecology, 51, 408-418. https://doi.org/10.2307/1935376

[14] Werner, E.E. and Hall, D.J. (1977) Competition and Habitat Shift in Two Sunfishes (Centrarchidae). Ecology, 58, 869-976. https://doi.org/10.2307/1936222

[15] Lagler, K.F., Bardach, J.E. and Miller, R.R. (1962) Ichthyology. John Wiley and Sons Inc., New York, USA, $230 \mathrm{p}$.

[16] Siaka, B., Essetchi Kouamelan, P., Nahoua, I., Ouattara, V., N’Douba, V. and N'Guessan Kouassi, J. (2008) Régime alimentaire de Distichodus rostratus (Characiformes, Distichodontidae) dans un bassin Ouest africain (fleuve Bandama, Côte d'Ivoire). Science et Nature, 5, 167-176.

[17] Greenberg, L.A. (1991) Habit Use and Feeding Behavior of Thirteen Species of Benthic Stream Fishes. Environmental Biology of Fishes, 31, 389-401.

https://doi.org/10.1007/BF00002364 